\title{
ASSESSMENT OF ADHERENCE TO POST-EXPOSURE CONDUCTS AMONG HEALTH WORKERS: TRANSLATION AND CULTURAL ADAPTATION OF AN INSTRUMENT ${ }^{1}$
}

\author{
Adriane Corrêa Jansen², Maria Helena Palucci Marziale, Cláudia Benedita dos Santos ${ }^{4}$, Rosana Aparecida \\ Spadotti Dantas ${ }^{5}$, Nai-Ying Ko
}

2 Paper resulting from the dissertation - Cultural adaptation and validation for Brazil of the tool Comply with post-exposure management among health care workers for nursing professionals, presented to the Programa Interunidades de Doutoramento em Enfermagem at the Universidade de São Paulo (USP) at Escola de Enfermagem de Ribeirão Preto (EERP) in 2014. Project funded by the Brazilian Scientific and Technological Development Council.

2 Ph.D. in Sciences. Full Professor, Escola Técnica de Saúde, Universidade Federal de Uberlândia. Uberlândia, Minas Gerais, Brazil. E-mail: dijansen@estes.ufu.br

${ }^{3}$ Ph.D. in Nursing. Full Professor, Departamento de Enfermagem Geral e Especializada, EERP/USP. Ribeirão Preto, São Paulo, Brazil. E-mail: marziale@eerp.usp.br

${ }^{4}$ Ph.D. in Statistics. Associate Professor, Departamento de Enfermagem Materno-Infantil e Saúde Pública, EERP/USP. Ribeirão Preto, São Paulo, Brazil. E-mail: cbsantos@eerp.usp.br

${ }^{5}$ Ph.D. in Nursing. Associate Professor, Departamento de Enfermagem Geral e Especializada, EERP/USP. Ribeirão Preto, São Paulo, Brazil. E-mail: rsdantas@eerp.usp.br

${ }^{6}$ Ph.D in Nursing. Professor, Department of Nursing, National Cheng-Kung University. Tainan, Taiwan. E-mail: nyko@mail. ncku.edu.tw

\begin{abstract}
Methodological study, undertaken between July/2011 and June/2012, whose aim was to translate and culturally adapt to Brazil the Chinese instrument (健康照顧專業人員職業性危害針扎後之追蹤) that assesses health professionals' intent to comply with conducts post-occupational exposure to biological material. The sample was random and consisted of 15 nursing professionals, exposed to biological material. The cross-cultural adaptation process showed to be satisfactory and the semantic validation evidenced that the instrument is understandable $(73.3 \%)$, appropriate for the Brazilian culture and well accepted $(85.2 \%$ of the items with favorable answers). The use of this instrument in Brazilian studies will permit broader discussions about actions to prevent occupational exposure to biological material and the planning of new strategies for the health services.
\end{abstract}

DESCRIPTORS: Exposure to biological agents. Nursing. Intention. Occupational health. Validation studies.

\section{AVALIAÇÃO DA ADESÃO ÀS CONDUTAS PÓS-EXPOSIÇÃO ENTRE TRABALHADORES DE SAÚDE: TRADUÇÃO E ADAPTAÇÃO CULTURAL DE INSTRUMENTO}

RESUMO: Estudo metodológico, realizado no período de julho/2011 a junho/2012, que objetivou traduzir e adaptar culturalmente para o Brasil o instrumento chinês (健康照顧專業人員職業性危害針扎後之追蹤) que avalia a intenção dos profissionais de saúde de cumprir as condutas pós-exposição ocupacional a material biológico. A amostra foi aleatória e constituída por 15 profissionais de enfermagem, expostos a material biológico. O processo de adaptação cultural mostrou-se satisfatório e a validação semântica evidenciou que o instrumento é compreensível (73,3\%), adequado à cultura brasileira e bem aceito $(85,2 \%$ dos itens com respostas favoráveis). O uso do instrumento em pesquisas brasileiras possibilitará ampliar a discussão sobre ações de prevenção à exposição ocupacional a material biológico e planejamento de novas estratégias para os serviços de saúde.

DESCRITORES: Exposição a agentes biológicos. Enfermagem. Intenção. Saúde do Trabalhador. Estudos de Validação.

\section{EVALUACIÓN DE LA ADHESIÓN A LAS CONDUCTAS POST- EXPOSICIÓN ENTRE TRABAJADORES DE SALUD: TRADUCCIÓN Y ADAPTACIÓN CULTURAL DE INSTRUMENTO}

RESUMEN: Estudio metodológico, desarrollado entre julio/2011 y junio/2012, con objeto de traducir y adaptar culturalmente para Brasil el instrumento chino (健康照顧專業人員職業性危害針扎後之追蹤) que evalúa la intención de los profesionales de salud de cumplir con las conductas post-exposición profesional a material biológico. La muestra fue aleatorizada y abarcó a 15 profesionales de enfermería expuestos a material biológico. El proceso de adaptación cultural se mostró satisfactorio y la validación semántica evidenció que el instrumento es comprensible (73,3\%), adecuado a la cultura brasileña y bien aceptado $(85,2 \%$ de los ítems con respuestas favorables). El uso del instrumento en investigaciones brasileñas posibilitará ampliar la discusión sobre las acciones de prevención a la exposición ocupacional a material biológico y la planificación de nuevas estrategias para los servicios de salud.

DESCRIPTORES: Exposición a Agentes Biológicos. Enfermería. Intención. Salud Laboral. Estudios de Validación. 


\section{INTRODUCTION}

At health care institutions, the workers are exposed to biological, chemical, physical, psychosocial risks and anti-ergonomic situations. ${ }^{1}$ The execution of professional activities in environments where these risks are present can cause diseases and/or occupational accidents. ${ }^{2}$

As regards the biological risks, the infectious agents that cause occupational infections and most frequently affect the health workers are the $\mathrm{Hu}$ man Immunodeficiency Virus (HIV), Hepatitis B (HBV) and Hepatitis C (HCV). Although preventing exposure is the main measure to avoid this kind of infection, adopting appropriate postexposure conducts is also an important protection factor to avoid occupational illness. ${ }^{1}$

The World Health Organization estimates that three million percutaneous accidents involving needles contaminated with biological material happen each year among health workers around the world each year. ${ }^{3}$ In Brazil, the systemization of occupational accidents involving biological material is recent, impeding knowledge about the magnitude of this problem, ${ }^{4}$ but several studies undertaken in the country confirm that nursing workers are constantly exposed to biological material and present the highest rates of occupational accidents involving this kind of exposure. ${ }^{2,5-9}$ Most accidents are due to percutaneous exposure with hollow needles and affect the fingers. The causes of occupational exposure include inappropriate work conditions, non-use of safety material like Individual Protection Equipment (IPE) and retractable-needle devices, inappropriate disposal of piercing-cutting material, ${ }^{5-6}$ work overload, fate, professional error and neglect. ${ }^{2}$

That reality is a source of concern, as compliance with the post-exposure conducts remains unsatisfactory among the health professionals. ${ }^{10-12}$ Studies show that about $30 \%$ of the professionals who are victims of accidents involving biological material do not seek specialized clinical care to start the recommended post-exposure conducts. ${ }^{11-12} \mathrm{~A}$ study about adherence to prophylactic treatment after exposure to biological material revealed that 339 professionals (53\% of the study population) who started clinical monitoring dropped out of the treatment before the recommended period. ${ }^{10}$ The high abandonment rate of monitoring post exposure to biological material reveals the lack of importance the workers attribute to this kind of exposure and, what the institutions are concerned, an often ineffective monitoring system of the workers who were victims. ${ }^{10}$

In an analysis of the scientific articles on validated tools to quantify the psychosocial variables involved in health behavior, necessary to prevent infections, due to occupational exposure to potentially contaminated biological material, found that there are no Brazilian tools on conducts post exposure to biological material. These articles were selected in a search in the electronic databases ISI Web of Knowledge, Scopus, PubMed, Lilacs and in the SciELO Collection, published between 1989 and 2011, in Portuguese, Spanish and English, and identified through the search mechanism of keywords/descriptors (exposure to biological agents, post-exposure conducts, occupational risks, attitude, adherence, nursing, nursing team, health staff, scales and validation studies). Among the tools found, developed in other countries, the tool called Comply with postexposure management among health care workers, originally developed in Chinese (健康照顧專業 人員職業性危害針扎後之追蹤). ${ }^{13}$

That tool was selected for use in this study because it is focused on conducts after exposure to biological material in health, as it adopts a theoretical framework to support its discussions and analyses and because the authors submitted it to face and content validation and to the reliability test, which assessed its internal consistency, using Cronbach's alpha (between 0.60 and 0.95 on the six subscales. Although the original tool was elaborated for health professionals, the validation process was undertaken in a sample of nurses.

To elaborate this tool, the authors followed the reference framework of the Theory of Planned Behavior (TPB). The objective of this theory is to predict and understand the motivational influences of behavior. The main factor that determines the behavior is the intention, which results from three variables: the attitudes (the individual's positive or negative assessment of a certain behavior), the subjective norm (the individual's perception of the social pressures he receives to accomplish a certain behavior or not) and the perceived behavioral control (refers to the facility and/or difficulty the individual perceives to perform a behavior).$^{14}$

As there is no tool in Brazil that makes this assessment and the tool found was developed in another language, country and culture, the objective in this research was to translate and 
adapt to the Brazilian culture the tool Comply with post-exposure management among health care workers. ${ }^{13}$

\section{METHOD}

Quantitative, methodologica study ${ }^{15}$ that was aimed at culturally adapting a tool that assesses the intention to comply with conducts post-occupational exposure to biological material.

In the scientific literature, several proposals are found to develop cultural adaptation studies of research tools. One of these proposals, published in 1993 and later updated, recommends the following steps: initial translation of the original tool, synthesis of translations, back-translation, assessment of translations by an expert committee, pretest, submission of the process to a committee of authors or researchers responsible for the tool. ${ }^{16-}$ ${ }^{17}$ These steps were improved in other studies that also suggested obtaining a synthesis after the initial translations, and also proposed the submission of this synthesis to the expert committee before the back-translation, permitting the early detection of errors or comprehension problems. ${ }^{18}$ Some Brazilian researchers used this proposal, adding the semantic analysis phase of the items, before the pretest, aiming to identify how the interviewees understand the items and whether they have any suggestions to modify some of them. ${ }^{19-21}$

Thus, in this study, the following steps were accomplished in this study: translation of the tool to Portuguese, obtaining the translation synthesis, assessed by an expert committee, back-translation, obtaining a consensus version in the language of origin and comparison with the original version, semantic analysis of the items. The remaining steps, which include the pretest and the analysis of the psychometric properties, which are necessary to validate the tool, will be developed in a later stage.

To undertake the semantic analysis step, two forms were used (General Impression Form - GIF, and Specific Form - SF), elaborated by the Disabilities Kids (DISABKIDS®) group and translated and culturally validated for Brazil by Brazilian researchers..$^{22}$ The use of these questionnaires permitted a general assessment of the tool and a specific assessment, including all subscales presented in the tool. DISABKIDS ${ }^{\circledR}$ is a European project that studies the improvement in the quality of life of children with chronic health conditions and which has developed a set of health-related quality of life tools, which have been published in Brazil since 2004. Among the recommendations of the DISABKIDS ${ }^{\circledR}$ group, ${ }^{23}$ when a tool has a large number of items, the sample and the items need to be divided in groups for the use of the SF to guarantee the reliability of the answers and to avoid exhaustion and fatigue due to $\mathrm{q}$ detailed assessment of all items in a tool.

To adapt the tool chosen to the Brazilian reality, the choice was made to include the categories auxiliary nurse, baccalaureate nurse and nursing technician into the study sample, and not just the baccalaureate nurse category like in the original tool. The first author of the original tool authorized and approved this change in the sample used to adapt the tool to Brazil.

To comply with the guidelines of the DISABKIDS $^{\circledast}$ group and obtain the assessments of the groups for the specific assessment of the tool, a probabilistic sample of 15 nursing professionals was defined, who had been exposed to occupational accidents involving biological material, with five subjects from each professional nursing category. The study included the nursing professionals who were active at the time of the data collection, that is, who were not on vacation, medical leave or any other type of leave. A draft was undertaken in the software Statistical Package for the Social Sciences (SPSS), version 17, to define the sample.

The semantic analysis step was undertaken at a university hospital in the interior of Minas Gerais, Brazil, between 05/14 and 05/21/2012. The choice of this hospital is due to the fact that it has sufficient numbers of professionals from the three categories to be equally represented in the definition of the sample.

The study population consisted of 110 nursing professionals working at this hospital, who were exposed to occupational accidents involving biological material between 2010 and 2012, according to a list provided by the institution's Specialized Occupational Safety and Medicine Engineering Service (SESMT).

The project was submitted to the Institutional Review Board at the institution where the study was undertaken, according to National Health Council Resolution 196/96, which regulated research involving human beings at the time of the study, ${ }^{24}$ and received a favorable opinion under Approval Protocol 041/12. In compliance with this Resolution, the Informed Consent Form 
was elaborated and signed, which guarantees the research subjects' free and voluntary participation, as well as their anonymity and the secrecy of the collected information.

The adaptation process of the tool Comply with post-exposure management among health care workers started after the first author granted authorization for its use, who forwarded the original version in Chinese by e-mail. To use the forms of the DISABKIDS ${ }^{\circledR}$ group, in the semantic analysis, the representative of this group in Brazil granted preliminary authorization.

The original version of the tool Comply with post-exposure management among health care workers is self-applied and consists of two parts of sequential questions, one related to the research subject's Basic Data and the other containing information on the most recent Exposure to occupational risk to biological material. After these items, the authors presented six subscales, which were elaborated using Likert-type questions, with specific response options for each. These subscales are numbered and are related to the TPB constructs, which its authors define as follows: 1- Attitudes of health professionals accidentally exposed to biological material, defined as the degree of positive or negative assessment related to compliance with post-exposure conducts; 2-Subjective norms, which refers to the health professionals' perceived social pressure to comply with post-exposure conducts. The next three subscales address the perceived behavioral control, defined as the health professionals perceived difficulty or facility to accomplish post-exposure conducts. This perception is measured through:3-knowledge, 4- self-efficacy and 5- resources. The sixth and last subscale is called Intent to comply with conducts after exposure to occupational risk and was defined as the intention to inform future lesions, participate in counseling, receive post-exposure vaccination and prophylaxis and return for final serum status monitoring tests. ${ }^{13}$

A short version of the third version of this tool, containing only the questions related to the subjects' basic data and the six subscales, was used in the semantic analysis phase. The second part of the tool, which characterizes the exposure to occupational risk to biological material, was excluded in this phase to reduce the number of questions, as the two forms elaborated by the DISABKIDS ${ }^{\circledR}$ Group would also be used. The first part was maintained to characterize the subjects who participated in this phase, supporting the discussion of the results.

The GIF consists of four questions with objective alternative answers, such as: What did you think of our questionnaire in general? Are the questions understandable? And about the alternative answers? Did you face any difficulty to use them? Are the questions important to your situation? Three other open questions allow the subject to manifest his/her suggestions for changes or additions in the tool, besides asking whether there was any question (s)he did not want to answer.

The SF contains three questions with closed answers, which assess the importance attributed to the item (Is that important to your situation?), the comprehension difficulties the subject faces (Is it difficult for you to understand this question?) and the subject's opinion on the clarity of the alternative answers to each item (Are the alternative answers clear and consistent [in accordance] with the question?). In addition, space is offered for the subject to reformulate the item (How would you say/express that?) and further space for the subject to describe the item as (s)he understands it (Could you tell me, in your words, what this question means to you?).

To start the first step of the translation and adaptation process of the tool to the Brazilian culture, a specialized translation company was hired for the initial translations of the original tool. Independent, Brazilian or naturalized, bilingual (Portuguese/Chinese) translators developed both translations. Next, these translations were analyzed and summarized in a consensus version in Portuguese, obtained during a meeting held at the Universidade de São Paulo at Escola de Enfermagem de Ribeirão Preto (EERP/USP), involving two researchers engaged in the research and one translator who was a final-year nursing student from Taiwan, a naturalized Brazilian who spoke Chinese fluently.

The expert committee, responsible for the second phase of the process, consisted of experts in the concepts the tool and the method explore, including one psychologist, faculty member with expertise in the theoretical framework the authors of the original tool use; two nurses, faculty members with knowledge on the method used in this study; and two nurses, faculty members who were Occupational Health researchers. The meeting took place at EERP/USP and also included the same translator as in the earlier phase. An evalu- 
ation document was elaborated with the list of all items from the Portuguese consensus version of the tool, including space to register each expert's assessment and suggestions for each type of equivalence under analysis (semantic, idiomatic, cultural, conceptual equivalence). The versions of the tool were considered equivalent when at least $80 \%$ of the experts agreed. ${ }^{25}$

After the end of the previous phase, the second version in Portuguese was obtained, which was then back-translated. The specialized company hired for the first translations was also responsible for the back-translations (from Portuguese to Chinese). The translations were developed by independent Chinese translators, resulting in two translated versions. The company guaranteed the translators' guarantee in writing.

To obtain a final version in Chinese, at the end of the back-translations, these were synthesized, involving the translators of the hired company, who had been responsible for the translation Portuguese/Chinese and a translator who was fluent in both languages.

This final version in Chinese was then forwarded to the first author of the original tool to compare with the final Chinese version, resulting in a favorable opinion, without any suggested changes. Thus, the third version of the instrument was obtained, to be forwarded to the semantic analysis after the data collection.

The semantic analysis of the items of this third version of the tool in Portuguese, was aimed at identifying, together with the subjects, the acceptance, relevance and understanding of the items and alternative answers of the tool for validation and whether they would suggest changes in any of these items.

In the data collection for this phase, all subjects in the sample answered the short version of the tool and the GIF. A certain group of subjects answered the SF, in accordance with the proposal of the DISABKIDS ${ }^{\circledast}$ group, also used in studies undertaken in Brazil..$^{21-22,26}$ The six subscales were divided in four subseries, so that each SF would present the item in one subseries, which permitted assessing the importance of each item, the difficulties found, the clarity of the alternative answers, as well as space for suggestions to reformulate the items when necessary.

Before completing this form, a draft was undertaken, maintaining the proportion of at least one subject from each professional nursing category to assess each subscale, as described in figure 1.

Figure 1 - Division of four subseries per items from each subscale and professional category

\begin{tabular}{|c|c|c|c|c|c|}
\hline Subseries & Subscales & \multicolumn{4}{|c|}{ Division of professional nursing categories } \\
\hline Subseries A & $\begin{array}{l}\text { Subscale } 1 \\
\text { (12 items) }\end{array}$ & Aux. Nurse & Aux. Nurse & Nurse & Nursing Technician \\
\hline Subseries B & $\begin{array}{l}\text { Subscale } 2 \\
(16 \text { items) }\end{array}$ & Aux. Nurse & Nurse & Nurse & Nursing Technician \\
\hline Subseries C & $\begin{array}{l}\text { Subscale } 3 \\
\text { (13 items) }\end{array}$ & Aux. Nurse & Nurse & Nursing Technician & Nursing Technician \\
\hline Subseries D & $\begin{array}{c}\text { Subscale } 4 \\
\text { (7 items) } \\
\text { Subscale } 5 \\
\text { (6 items) } \\
\text { Subscale } 6 \\
\text { (7 items) }\end{array}$ & Aux. Nurse & Nurse & Nursing Technician & - \\
\hline
\end{tabular}

The subjects received further clarifications on the study objectives and orientations on the data collection. Subjects who agreed to participate and one researcher signed two copies of the Informed Consent Form elaborated for this study. Next, the data collection tools were made available for the research participants to complete, in the presence of one of the authors, who wrote down any doubts the subjects mentioned on the time spent to complete it and their observations.

\section{RESULTS}

The translation and adaptation steps of the tool were undertaken in 11 months, between July/2011 and June/2012. 
As regards the first part of the tool (basic data), it was observed that, among the 15 nursing professionals who participated in the study, 13 were female, six married and six single and nine subjects were taking higher education. The mean age was 39.8 years (range from 22 to 60 years) and the average length of professional experience was 13.9 years (range between one and 35.6 years).

Some changes were made in the expert assessment phase, mainly resulting from the semantic and cultural equivalence assessments. One situation that can exemplify the cultural divergence between the two countries is the presence of the term "parents-in-law" in the items of subscale 2 - subjective norms as, in the original version of the tool, among the persons whom the subject considers significant, the parents-in-law figure beside the parents in the composition of the items on this subscale, showing an important trait of the Eastern culture.

The semantic analysis phase indicated the need for modifications in some parts of the text of the tool, like the replacement of some terms for example and the restructuring of some questions, aiming to make the tool clearer and easier to read.

It is highlighted that all modifications in these two steps received approval from the primary author of the original tool and have been described in figure 2 .

Figure 2 - Changes made in the tool after the expert assessment and semantic analysis

\begin{tabular}{|c|c|c|c|c|}
\hline Item & Change & Previous formulation & New formulation & Justification(s) \\
\hline All & $\begin{array}{l}\text { Replacement of the } \\
\text { term "needle" by } \\
\text { "biological mate- } \\
\text { rial" }\end{array}$ & - & - & $\begin{array}{l}\text { The term needle raised doubts } \\
\text { among the participants who did } \\
\text { not have accidents involving } \\
\text { this material, but had accidents } \\
\text { involving exposure to biologi- } \\
\text { cal material. }\end{array}$ \\
\hline Title & Reformulation & $\begin{array}{l}\text { Condutas de profis- } \\
\text { sionais da área da saúde } \\
\text { pós-exposição ocupacio- } \\
\text { nal por acidentes com } \\
\text { agulhas }\end{array}$ & \begin{tabular}{|l|} 
Adesão às Condutas Pós- \\
Exposição entre Trabalha- \\
dores de Saúde (ACPETS)
\end{tabular} & $\begin{array}{l}\text { Standardize the text regarding } \\
\text { the term "needle" and change } \\
\text { the title to the translation in } \\
\text { English (Comply with post- } \\
\text { exposure management among } \\
\text { health care workers). }\end{array}$ \\
\hline $\begin{array}{l}\text { Basic Data } \\
\text { Item } 9\end{array}$ & $\begin{array}{l}\text { Reformulation and } \\
\text { replacement by ex- } \\
\text { pression "biological } \\
\text { material" }\end{array}$ & $\begin{array}{l}\text { Você já sofreu acidente } \\
\text { de trabalho com agulhas? }\end{array}$ & $\begin{array}{l}\text { Quantas vezes você já } \\
\text { sofreu acidente de trabalho } \\
\text { com material biológico? } \\
\text { Dentre elas, notificou } \\
\text { quantas vezes? }\end{array}$ & $\begin{array}{l}\text { Due to the abovementioned } \\
\text { doubt involving the term } \\
\text { needle and the need to quantify } \\
\text { the number of occupational } \\
\text { accidents and notifications by } \\
\text { the subject. }\end{array}$ \\
\hline $\begin{array}{l}\text { Subscale } 2 \\
\text { Items } 2.1 \\
\text { till } 2.4\end{array}$ & $\begin{array}{l}\text { Withdrawal of term } \\
\text { "parents-in-law" }\end{array}$ & $\begin{array}{l}\text { Eu costumo seguir as } \\
\text { opiniões dos meus pais } \\
\text { (sogros) }\end{array}$ & $\begin{array}{l}\text { Eu costumo seguir as } \\
\text { opiniões dos meus pais }\end{array}$ & $\begin{array}{l}\text { Change suggested by the expert } \\
\text { committee to achieve the cul- } \\
\text { tural equivalence of the tool }\end{array}$ \\
\hline
\end{tabular}

It was verified that $13(86.7 \%)$ out of 15 participants did not question the number of items in the tool, while two subjects $(13.3 \%)$ manifested that they considered it was long. The time to complete the short version of the tool and the two forms used for the semantic analysis ranged between 23 and 86 minutes, with a mean duration of $47 \mathrm{~min}$ utes. This calculation includes the time spent on the subjects' comments and the solution of doubts. The time spent to complete the short version of the tool only was not measured.
In the analysis of the answers provided in the completion of the GIF, the 15 subjects' assessment of the Semantic Analysis phase ranged between very good $(53.3 \%)$ and good $(46.7 \%)$. As to the understanding of the items, $73.3 \%$ considered that they were easy to understand and $26.7 \%$ that the items were sometimes difficult to answer. The importance of the items showed expressive results, as $86.7 \%$ considered they were very important and $13.3 \%$ sometimes important. These results are displayed in Table 1. 
Table 1 - Results from General Impression Form, ${ }^{23}$ used in the semantic analysis phase of the tool Adesão às Condutas Pós-Exposição entre Trabalhadores de Saúde (ACPETS)

\begin{tabular}{llrr} 
Items from general impression form & \multicolumn{1}{c}{ Alternative answers } & $\begin{array}{c}\text { Answer frequency } \\
\text { (n=15) }\end{array}$ \\
\cline { 3 - 4 } & & $\mathbf{n}$ & \% \\
\hline What did you think of our questionnaire in general? & Very good & 8 & 53.3 \\
& Good & 7 & 46.7 \\
& Regular/more or less & - & - \\
Are the questions understandable? & Easy to understand & 11 & 73.3 \\
& Sometimes difficult to understand & 4 & 26.7 \\
And about the alternative answers? Was it difficult for & Not understandable & - & - \\
you to use them? & None/no difficulty & 6 & 40 \\
& Some difficulties & 9 & 60 \\
Are the questions important to your situation? & Many difficulties & - & - \\
& Very important & 13 & 86.7 \\
& Sometimes important & 2 & 13.3 \\
\hline
\end{tabular}

Among the problems diagnosed through the completion of the GID, the least favorable results were found for the third question, related to the alternative answers. The subjects who informed this type of difficulties included four auxiliary nurses, three baccalaureate nurses and two nursing technicians. The only nursing auxiliary who did not mention difficulties with the alternative answers held a higher education degree.

As regards the results of the SF, it was verified that, out of 61 items, $52(85.2 \%)$ showed answers favorable to the questions on the form, while only nine presented problems.

The SF assesses the 61 items in the tool through three questions, resulting in 183 answers. There were 18 answers with negative assessments, 11 of which by auxiliary nurses, five by nursing technicians and two by baccalaureate nurses.

To mitigate the difficulties and enhance the understanding of the tool as a whole, some changes were made to some alternative answers (subscales 1, 2, 4 and 6) and to the formulation of some items (subscales 1, 3 and 5). Another change made was the inclusion of a general informative text before the start of the six subscales (Information: one the next pages, you will answer six scales with alternative answers related to your opinion and/or understanding of accidental exposure to biological material).
It is highlighted that, in subscale 2 (subjective norms), the items take into account the expectations of people significant to the nursing professionals (parents, siblings, partners or boy/ girlfriend and supervisor). It was observed that, among the research participants, five subjects had doubts among the alternative answers (I completely disagree, I disagree, no opinion, I agree and I completely agree) as the items did not apply to their situation, for example not having parents who were alive, being an only child, not having a partner/boyfriend. As they did not find an appropriate alternative answer, they chose the option No opinion or left the item unanswered. The change made was the addition of the option do not apply (example: Items 2.1 till 2.4 do not apply), for the subject to use when the formulation of the item is not related to their situation. The total number of items in the subscale was left unchanged, as the option added was left unnumbered and will be used to justify the reason why the subject possibly did not answer that group of items.

In addition, before the list of items on that subscale, the following text was added: Use the option 'do not apply' when the formulation of the item is not related to your situation, for example not having parents who are alive, being an only child, not having a partner or boyfriend. 


\section{DISCUSSION}

Among the difficulties found along the trajectory between the translation and adaptation of the tool Adesão às condutas pós-exposição entre trabalhadores de saúde (ACPETS), the questions deriving from working with a tool developed in Chinese can be mentioned. The lack of translators fluent in Chinese/Portuguese of Brazilian (translations) or Chinese (back-translations) origins who were not affiliated with a company turned that into the strategy for this study. This strategy did not interfere in the changes in the items' meaning, as confirmed by the author of the original tool, who compared the adapted with the original version.

The participation of the expert committee contributed to the assessment of the instrument items, resulting in some changes, mainly regarding semantic and cultural equivalence. After this step, a new version was obtained, with changes in the text of the items and in some alternative answers for the sake of the clarity and understanding of the tool.

The results from the analysis of the answers to the GIF and SF demonstrate that the category of the auxiliary nurses showed greater difficulty to answer the tool than the nursing technicians and nurses.

The nursing work is characterized by internal division, according to different educational backgrounds among the three categories, that is, nurses with a higher education level, nursing technicians with a secondary level and auxiliary nurses with primary education. ${ }^{27}$ This entails distinctions in the learning and technical qualification processes for work practice at each level, making them unequal. ${ }^{28}$

The auxiliary nursing category contains a high percentage of workers inside the profession and is also responsible for direct patient care. Nevertheless, some authors mention that knowing what characterizes this category corresponds to knowledge of the nursing techniques, without further contact with the knowledge related to the systemization of scientific principles underlying the techniques, nor with the knowledge resulting from nursing research. According to those authors, these characteristics compromise the quality of nursing care and the quality of health services, as they consider that nursing care cannot be delivered without technical-scientific foundations, as it is related to a set of often invasive actions that entails risks or potential damage to the patients and the workers. ${ }^{28}$

Good acceptance of the adapted version of the tool was found, which needs to be validated, as the analyses based on the forms used in the semantic analysis phase indicated difficulties with some items, but most of them received positive assessments from the subjects. Nevertheless, the difficulties, related to the understanding of some items and reports on the lack of clarity and consistency in some alternative answers, did not impede answers coherent with the objective of the item formulated.

\section{CONCLUSION}

The semantic analysis of the adapted version of the Chinese tool to Portuguese showed the need for some changes in its formulation. Besides these changes, the need was verified to exclude the professional category of auxiliary nurses to continue the validation process of the psychometric properties of the tool, in view of the difficulties displayed and observed in the semantic analysis.

The results obtained show good acceptance of the tool and the maintenance of semantic, idiomatic, cultural and conceptual equivalence, as well as the face validity. Other statistical tests to assess the psychometric properties of the tool will be applied, with a view to the further availability of the tool in Brazil.

In conclusion, the relevance of selecting tools of other linguistic origins derives from the potential cooperation and the perspective of international relations in Occupational Health. The use of the tool in Brazilian research will permit a broader discussion among researchers on actions to prevent occupational exposure to biological material and the planning of new strategies for use in health services.

\section{REFERENCES}

1. Ministério da Saúde (BR). Secretaria de Vigilância em Saúde. Departamento de DST, Aids e Hepatites Virais. Recomendações para terapia antirretroviral em adultos infectados pelo HIV - 2008. Brasília (DF): 2010

2. Silva EJ, Lima MG, Marziale MHP. O conceito de risco e os seus efeitos simbólicos nos acidentes com instrumentos perfurocortantes. Rev Bras Enferm. 2012 Set-Out; 65(5):809-14. 
3. Prüss-Ustün A, Rapiti E, Hutin Y. Sharps injuries: Global burden of disease from sharps injuries to healthcare workers. Environmental Burden of disease series. Geneva: World Health Organization; 2003. p.1-39.

4. Rapparini C, Reinhardt EL. Manual de implementação: programa de prevenção de acidentes com materiais perfurocortantes em serviços de saúde. Adaptado de "Workbook for designing, implementing, and evaluating a sharps injury prevention program" - Centers for Disease Control and Prevention, 2008. São Paulo (SP): Editora Fundacentro; 2010.

5. Chiodi MB, Marziale MHP, Mondadori RM, Robazzi MLCC. Acidentes registrados no Centro de Referência em Saúde do Trabalhador de Ribeirão Preto, São Paulo. Rev Gaúcha Enferm. 2010 Jun; 31(2):211-7.

6. Vieira M, Padilha MI, Pinheiro RDC. Analysis of accidents with organic material in health workers. Rev Latino-Am Enferm. 2011 Jan-Feb; 19(2):332-9.

7. Marziale MHP, Galon T, Cassiolato FL, Girão FB. Implantação da Norma Regulamentadora 32 e o controle dos acidentes de trabalho. Acta Paul Enferm. 2012; 25(6):859-66.

8. Valim MD, Marziale MHP. Avaliação da exposição ocupacional a material biológico em serviços de saúde. Texto Contexto Enferm. 2011; 20(esp):138-46.

9. Valim MD, Marziale MHP, Richart-Martínez M, Sanjuan-Quiles A. Instruments for evaluating compliance with infection control practices and factors that affect it: an integrative review. J Clin Nurs. 2014 Jun; 23(11-12):1502-19.

10. Cespedes LDM, Sarquis LMM, Scussiato LA, Miranda FMD, von Stein Jr A. Estudo da adesão de trabalhadores com acidentes de trabalho notificados. Cogitare Enferm. 2010 Abr-Jun; 15(2):245-9.

11. Oliveira AC, Gonçalves JA. Ocupational accident with sharp edge material among workers of operating center. Rev Esc Enferm USP. 2010 AbrJun; 44(2):482-87.

12. Pimenta FR, Ferreira MD, Gir E, Hayashida M, Canini SRMS. Care and specialized clinical followup of nursing professionals who have been victims of accidents with biological material. Rev Esc Enferm USP. 2013 Jan-Mar; 47(1):198-204.

13. Ko NY, Yeh SH, Tsay SL, Ma HJ, Chen CH, Pan $\mathrm{SM}$, et al. Intention to comply with post-exposure management among nurses exposed to blood and body fluids in Taiwan: application of the theory of planned behavior. J Hosp Infect. 2011 Abr; 77(4):32126.

14. Ajzen I. The theory of planned behavior. Organizational Behavior and Human Decision Processes. 1991 Dec; 50(2):179-211.
15. Kerlinger FN. Metodologia da pesquisa em ciências sociais. São Paulo (SP): EPU; 1979.

16. Guillemin F, Bombardier C, Beaton D. Cross-cultural adaptation of health-related quality of life measures: literature review and proposed guidelines. J Clin Epidemiol. 1993 Dec; 46(12):1417-32.

17. Beaton DE, Bombardier C, Guillemin F, Ferraz MB. Guidelines for the process of cross-cultural adaptation of self-report measures. Spine. 2000 Dec; 25(24):3186-91.

18. Ferrer M, Alonso J, Prieto L, Plaza V, Monso E, Marrades R, et al. Validity and reliability of the St George's Respiratory Questionnaire alter adaptation to a different language and culture: the Spanish example. Eur Respir J. 1996; 9(6):1160-6.

19. Echevarría-Guanilo ME, Rossi LA, Dantas RA, Santos CB. Cross-cultural adaptation of the burns specific pain anxiety scale - BSPAS to be used with Brazilian burned patients. Rev Latino-Am Enferm. 2006 Jul-Ago; 14(4):526-33.

20. Dantas RAS, Silva FS, Ciol MA. Psychometric properties of the Brazilian Portuguese versions of the 29- and 13-item scales of the Antonovsky's Sense of Coherence (SOC-29 and SOC-13) evaluated in Brazilian cardiac patients. J Clin Nurs. 2014 Jan; 23(1-2):156-65.

21. Pelegrino FM, Dantas RAS, Corbi ISA, da Silva Carvalho AR, Schimidt A, Pazin Filho A. Crosscultural adaptation and psychometric properties of the Brazilian-Portuguese version of the Duke Anticoagulation Satisfaction Scale. J Clin Nurs. 2012; 21(17-18):2509-17.

22. Fegadolli C, Reis RA, Martins STA, Bullinger $M$, Santos CB. Adaptação do módulo genérico DISABKIDS ${ }^{\circledR}$ para crianças e adolescentes brasileiros com condições crônicas. Rev Bras Saúde Mater Infant. 2010 Jan-Mar; 10(1)95-105.

23. DISABKIDS Group. Pilot test manual. Leiden (NL): The DISABKIDS Group; 2002.

24. Ministério da Saúde (BR). Conselho Nacional de Saúde, Comissão Nacional de Ética em Pesquisa. Resolução n. 196 de 10 de outubro de 1996: diretrizes e normas regulamentadoras de pesquisa envolvendo seres humanos. Brasília (DF): MS; 1996.

25. Pasquali L. Princípios de elaboração de escalas psicológicas. Rev Psiquiatr Clín. 1998; 25(5):206-13.

26. Deon KC, Santos DMSS, Reis RA, Fegadolli C, Bullinger M, Santos CB. Translation and cultural adaptation of the Brazilian version of DISABKIDS ${ }^{\circledR}$ Atopic Dermatitis Module (ADM). Rev Esc Enferm USP. 2011 Abr-Jun; 45(2):450-7.

27. Gottems LBD, Alves ED, Sena RR. Brazilian nursing and professionalization at technical level: a retrospective analysis. Rev Latino-Am Enferm. 2007 Set-Out; 15(5):1033-40. 
28. Peduzzi M, Anselmi ML. O processo de trabalho em: http://bvsms.saude.gov.br/bvs/publicacoes/ do auxiliar de enfermagem. Formação [online]. 2003 Jan [acesso 2014 jan 29]; 7(1):73-87. Disponível profae/Revista2007.pdf 